\title{
O projeto filosófico-educativo dos helenos
}

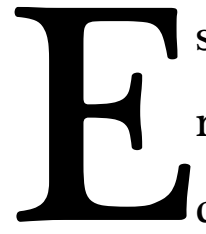
ste número de Filosofia e Educação, dedicado à educação na Grécia Antiga, concentra-se na análise e na descrição do processo conducente à formulação do problema social e cultural da Educação. Embora a difusão do letramento na Cultura grega obrigue o fulcro da questão a convergir na Atenas dos sécs. V-IV a.C., a complexidade do processo educativo não poderá ser abarcada se a Educação não for inserida no horizonte da História da Grécia, nos períodos Arcaico e Clássico.

\section{Homero e a tradição poética}

A necessidade dessa inserção é justificada pela circunstância de, na sua origem, os conteúdos em que assenta o projeto educativo grego irem sendo gradualmente fixados na Literatura e na Cultura, a partir dos meados do séc. VIII a.C., nas obras de gênese oral que a tradição consagrará como as epopeias de Homero e os poemas didáticos de Hesíodo. A avaliar pelos abundantes indícios em obras compostas a partir da época clássica, a Poesia de Homero e Hesíodo contribuiu para a formação de uma consciência comum. Mostra-o a adoção pelos Gregos do nome de Heleno, filho de 
Deucalião, como seu antepassado, e a escolha de "Hélade", como designação da região por todos habitada.

Sobre essa herança em formação trabalham os poetas líricos, cujas composições explicitamente registram ideais de comportamento que espelham modelos educativos definidos, bem como os tragediógrafos, cujas criações transpõem para o séc. $\mathrm{V}$ quadros e valores inspirados na Epopeia. Temos, porém, de esperar pelo séc. IV para encontrarmos, além das referências pontuais que sobrevivem em curtos fragmentos dos pensadores pré-socráticos (por exemplo, Demócrito; H. Diels, W. Kranz, Die Fragmente der Vorsokratiker: DK68B33), nas obras de Platão (427-347) e Aristóteles (384?-322?), as abordagens que condensam a constituição da temática da educação como problema que as comunidades gregas têm de enfrentar e resolver.

Bastará atentar nesta enumeração para nos darmos conta da natureza telescópica do processo pelo qual a educação é introduzida no mundo grego, através da permanente reatualização dos contornos definidores da sua identidade cultural. Pois, se a substância da educação se acha disseminada pela polifacetada recepção de um conjunto de cantos que a memória coletiva vai recolhendo das suas origens orais, os quais, a partir do séc. VIII, se vão deixando fixar pela escrita, é claro que o projeto educativo não 
poderá ser abordado independentemente da tradição "mitopoética" da qual nasce.

Esta constatação obriga-nos a inquirir sobre as razões que fazem de Homero o "educador dos Gregos" (Platão, República X 606e), buscando o esclarecimento das condições que concretizam a prolongada importação de que a sua obra é objeto. Para responder a esta pergunta é necessário começar por definir as balizas espaciais e temporais que delimitam o processo analisado pelo conjunto de estudos aqui reunidos.

No período compreendido (sécs. VIII-IV a.C.) - cujas balizas nada têm de arbitrário, como se verá -, a Cultura Grega incorpora o agregado das cidades-estado, dominantes nos territórios costeiros que se estendem do Norte da Ásia Menor ao Sul da península Itálica, passando, na Europa, pela linha da costa que vai do estreito de Bósforo até à península dos Balcãs, unificando as numerosas ilhas disseminadas pelo mar Egeu, das quais sobressaem Creta e a Sicília.

Ora, será a amplitude dessa extensão territorial que primeiro nos faz sermos confrontados com a evidência da identidade cultural grega. Se perguntarmos que fator, ou fatores, explicam essa identidade e a unidade cultural que associa comunidades tão distantes, persistindo no tempo e no espaço do mediterrâneo oriental, imediatamente encontraremos resposta no fato de em 
todas se falar a mesma Língua, a despeito das variedades dialetais a que é sujeita. A partir da decisão de manutenção dessa Língua, torna-se plausível aceitar que Homero e os seus continuadores tenham sido eleitos como suportes em que esse processo assentou, originando a tradição que fez deles obreiros da herança em que a identidade grega se acha consubstanciada.

Questionando as opções com que a tradição se confronta, é oportuno notar que, ao contrário do que se passa com Culturas hoje dominantes, os Gregos nunca dispuseram de um, ou de um conjunto de Livros Sagrados sobre os quais moldassem a sua identidade e edificassem o seu projeto educativo. Adiante veremos como, partindo das raízes homéricas, souberam buscar na autonomia do seu espírito crítico a distinção entre um Bem e um Mal que nenhuma potência sobre-humana lhes tinha transmitido.

Bom exemplo dessa empresa são máximas como o preceito délfico "Conhece-te a ti mesmo", que Sócrates sustenta ter adotado como princípio de conduta (Platão, Fedro 229e-230a), ou "Investiguei-me a mim mesmo" (Heráclito, fragmento 101). Mas a motivação desta procura do Saber manifesta-se na concepção de “ensino da virtude" praticado por qualquer Ateniense educado. No diálogo Protágoras, Platão coloca na boca do sofista, em defesa da sua tese de que a "excelência" ("virtude": arete) é ensinável, a concepção de acordo com a qual todos - pais, ama, tutor - 
concorrem para inculcar no jovem a distinção entre justo e injusto, nobre e vil, sacro e ímpio, mostrando-lhe como deve ou não deve proceder (325c-d). E de onde poderá cada um deles retirar ensinamentos senão da convivência com os seus concidadãos (Mênon 93a), os quais, em última análise, os retiram de Homero e dos poetas líricos e trágicos (a despeito do que pensará disso o Sócrates de Platão: República X 606e-608b)?

Mas não podemos pretender encontrar condensada exclusivamente no conteúdo dos Poemas a essência do "milagre" que distingue a Cultura grega de todas aquelas com quem convive, das quais recebe as influências que a sua criatividade soube recontextualizar em moldes inteiramente novos. Haverá, portanto, que atender a uma diversidade de fatores que contribuem para moldar a Educação helênica.

Em primeiro lugar, teremos de considerar a tecnologia à qual foi entregue a tarefa de fixar materialmente um acervo de mensagens, demasiado longas para a sua conservação poder ser integralmente confiada à memória humana: a escrita.

\section{A escrita}

O primeiro exemplo da "recontextualização" acima referida reside precisamente na tecnologia denominada pelos termos "escrita” e “escritura”, que se conjectura terem os Gregos recebido dos Fenícios, por volta de 750 a.C. E isto pela simples razão de a escrita 
fenícia recorrer a um silabário para parcialmente transcrever os sons produzidos pela fala, enquanto os Gregos inventaram um alfabeto fonético (no qual cada letra representa um som) para concretizar essa finalidade. À primeira vista, a diferença que separa um artefato do outro pode parecer desprezível, no entanto, as consequências que dela decorrem são imensas.

Essa diferença - cujo alcance é oportunamente notado por Platão, no Sofista e no Filebo (Fil. 16c-17e; Heródoto, Histórias V58, refere-se apenas à transformação das "letras": grammata) -, consistia na introdução das vogais para registrar os fonemas que na fala articulam os sons consonânticos num fluxo contínuo (Sof. 253a-b).

Com esta simples inovação é eliminada a ambiguidade fonética, resultante da necessidade de "ler" e pronunciar, por exemplo, a sílaba 'p?', como uma gama de fonemas vocálicos: $p a$, $p e, p i, p o, p u, o u$ intermédios. Dela decorrerão não só a liberação da escritura da autoridade do escriba - figura imprescindível para decifrar com precisão confiável uma mensagem corrente -, tornando a aprendizagem e utilização das "letras" não só acessível à generalidade dos cidadãos, como, praticamente, mostrando viável pela primeira vez a transcrição de longos textos.

Assim pôde ser iniciada não apenas a fixação pela escrita de extensos cantos, aglutináveis na unidade literária de poemas, como 
a Ilíada e a Odisseia. Mas também- numa perspectiva inteiramente diversa desta - foi tornado possível o registro de pensamentos, que, por não mais se acharem acorrentados aos suportes verbais que os exprimem (Platão, Fedro 275c-e, 276e-277a, 277e-278b), ganham o poder de referir os enunciados pensados e ditos ou escritos diretamente aos raciocínios, no contexto dos quais são produzidos. É desse modo que será promovido o desenvolvimento da reflexão e da crítica (Platão, Teeteto 189e-190a; Sofista 263e; Aristóteles, Da interpretação I 16a1-5).

\section{O letramento}

Esta é a inovação que possibilita o início do "letramento", processo pelo qual a introdução da escritura gradualmente se vai estendendo a todos os domínios em que a atividade política, pública e privada, precisa recorrer ao discurso. Com a difusão do letramento, a escrita não mais se achará confinada ao encargo de conservar mensagens, consideradas significativas, mas gradualmente ganhará o direito de registrar as novidades produzidas pela criação intelectual e promover a sua circulação. De modo que, tal como a mera aquisição das competências básicas "ler, escrever e contar"- possivelmente assimiladas por um número considerável de cidadãos (“Oração fúnebre”, de Péricles: Tucídides II, 35-46; Plutarco Vidas, “Aristides”, 7) - constitui o episódio inicial do processo de letramento de cada indivíduo, a difusão da 
utilização da escrita alfabética como registro do pensamento assinala a abertura da cultura grega para o longo caminho, no final, conducente à investigação do saber pelo saber (Aristóteles, Metafísica A2, 983a12-21).

\section{A escola}

O processo, contudo, não poderia ganhar raízes na estrutura das comunidades se não encontrasse apoio no conjunto de instituições que asseguram o seu funcionamento. Da Assembleia, em que os cidadãos deliberam sobre os desafios que se lhes deparam, ao Conselho, que executa as decisões tomadas, passando pelos tribunais, nos quais a Lei é aplicada, há uma rede de órgãos públicos, da qual depende a vida da comunidade. Todavia, todos eles requerem a preparação prévia dos que neles participam, condensada na instrução que habilita cada um a funcionar na instituição, com a competência que lhe é exigida. $\mathrm{Na}$ vida civil ou militar, na paz, na guerra ou na preparação para ela, o cidadão não pode ocupar um lugar de relevo na sociedade se não tiver passado pela escola.

E aí, de novo recorrendo ao Protágoras de Platão, encontramos a informação que nos deixa imaginar como funcionava uma escola, na Atenas do final do séc. V: 
[...] quando o aluno aprende a ler e começa a compreender o que está escrito, tal como faziam antes com os sons, dão-lhes em seu banquinho a ler as obras de bons poetas, que eles são obrigados a decorar, prenhes de preceitos morais, com muitas narrações em louvor e glória dos homens ilustres do passado, para que o menino venha a imitá-los por emulação e se esforce por parecer-se com eles. Do mesmo modo procedem os professores de cítara; envidam esforços para deixar temperantes os meninos e desviá-los da prática de ações más. Depois de haverem aprendido a tocar cítara, fazem-nos estudar as criações de outros grandes poetas, os líricos, a que dão acompanhamento de lira, trabalhando, desse modo, para que a alma dos meninos se aproprie dos ritmos e da harmonia, a fim de que fiquem mais brandos e, porque mais ritmados e harmônicos, se tornem igualmente aptos tanto para a palavra como para a ação. Pois em todo o seu decurso, a vida do homem necessita de cadência e harmonia. (Platão, Protágoras 325e-326b)

Nesse breve trecho do Protágoras se acha referida a quase totalidade dos elementos do processo educativo, como era encarado na Atenas do final do séc. V. A primeira fase da aprendizagem das letras é concluída com a aquisição, pela parte do aluno, da capacidade de ler uma mensagem escrita, com vista à compreensão do seu sentido. Atingida esta, é então que, tendo-lhe 
sido facultados textos escritos, da autoria de "grandes poetas", o exercício da leitura, reforçado pelo da memorização do texto, recitado em voz alta, reinsere no mundo da oralidade audível a mensagem apreendida pela vista (o procedimento pressupõe a existência de "livros", que sabemos serem formados por rolos de papiro colados). É a partir dessa prática que extensivamente se inicia o processo de assimilação dos conteúdos expressos no quadro dos valores nos quais reside a identidade cultural grega.

E aí, são uma vez mais convocadas outras práticas e técnicas, cuja função é reforçar a assimilação dos conteúdos absorvidos: a arte da música e da dança. É por elas que, através do ritmo, primeiro é ativada a mente pela memorização, depois, estendendose a todo o corpo, através da marcha e da dança, se amplifica proativamente o processo de recepção dos conteúdos educativos.

De seguida, entregam-nos os pais ao professor de ginástica, para que fiquem com o corpo em melhores condições de servir o espírito virtuoso, sem virem a ser forçados, por fraqueza de constituição, a revelar cobardia, tanto na guerra como em situações consemelhantes. Assim procedem os que mais podem, e podem mais os ricos, cujos filhos começam muito cedo a frequentar a escola e são os últimos a deixá-la. Quando saem da escola, a cidade, por sua vez, os obriga a aprender leis e a tomá-las como paradigma de conduta, para que não se deixem levar pela fantasia a praticar qualquer 
malfeitoria. Da mesma forma que procede o professor primário com os alunos que ainda não sabem escrever, traçando com seu estilete as letras e depois pondo-lhes nas mãos a tábula, e os obriga a escrever de acordo com o modelo apresentado: assim também prescreve leis a cidade, inventadas por antigos e virtuosos legisladores, exigindo que governem e sejam governados por elas. (Id., Ibid. 326c-d)

$\mathrm{Na}$ continuação, o passo faz culminar a exportação das palavras declamadas para os atos executados pelo exercício da ginástica, cuja finalidade última será não apenas desenvolver harmoniosamente o corpo, mas preparar o efebo para a luta no campo de batalha. No entanto, o culminar do processo educativo para Protágoras, a aprendizagem da virtude - só é atingido pelo contato e assimilação do conteúdo das leis da cidade.

Esta telescópica perspectiva sobre a Educação deixa-se por fim condensar na analogia que evidencia, tanto pela parte do sofista, a quem é atribuído o discurso, como pela do filósofo, que o registra, a consciência da unidade de todo o projeto de inserção dos jovens na comunidade. Apoiada no conjunto de instituições que congrega, com as suas leis, a cidade emula o mestre-escola, visando não mais à instrução de estudantes, mas à sua completa formação, como cidadãos. 


\section{Os sofistas e a revolução sofística}

As mudanças sentidas no processo da educação grega, na segunda metade do séc. V (ver as críticas na comédia de Aristófanes, As nuvens), são devidas à aparição dos sofistas. Até então, a instrução básica levada a cabo nas escolas (a partir dos sécs. VII-VI?) parece ter sido confiada a indivíduos cuja posição social - tratando-se de servos ou de escravos - não lhes permitia sair do anonimato. Todavia, com a implantação e o fortalecimento do regime democrático e a hegemonia sobre as outras cidades gregas, Atenas vai se tornar o centro político, econômico e cultural do mundo grego, atraindo intelectuais que convergem para a cidade, vindos de toda a Grécia.

Nos trinta anos que medeiam entre 462 e 430 a. C., a história da Hélade confunde-se com a de Atenas, no período áureo que veio a ser conhecido como o do "império de Atenas" ou o "século de Péricles" (495?-429). Duas figuras notáveis privaram pessoalmente com o tribuno que governa a cidade de 460 até à sua morte: Anaxágoras (de Clazómenas, na Ásia Menor: 500?-411?) e Protágoras (de Abdera, na Trácia: 485?-411). As críticas de Aristóteles aos dois pensadores determinam a diferença da sorte que a História lhes atribui. Enquanto o primeiro é considerado um "físico" e justamente incluído na tradição dos filósofos, seguindo demasiadamente à letra a lição de Platão, o segundo é 
injustamente rebaixado à condição de sofista, apesar de o próprio filósofo retratar tanto ele, como Górgias (de Leontini, na Sicília: 485?-380?), como os maiores expoentes da arte.

Mais de dois milênios passados sobre a justiça da avaliação de que foram objeto, ultrapassando antiquíssimas polêmicas, separamo-los dos muitos praticantes a quem a designação convém (veja-se o Eutidemo platônico) e, fazendo justiça à relevância das lições que nos deixaram, defendemos ser tempo de os abordarmos como filósofos. Esta correção obriga-nos a considerar brevemente perguntas como: O que são os sofistas? Que vêm fazer a Atenas, neste momento particular da sua História? De que modo contribuíram para a educação grega?

Os sofistas foram os primeiros a fornecer às cidades por onde passaram, ou onde se fixaram, um ensino público acima do nível básico. Não constituíram um grupo definido. Desenvolveram uma extensa panóplia de abordagens educativas e ensinaram uma ampla diversidade de matérias. Alguns eram estrangeiros e intelectuais de renome que viajavam de cidade em cidade exibindo o seu saber, por exemplo, em Festivais (Platão, Hípias Menor 363c-e Hípias Maior 281a-286c), que talvez tenham encontrado na Atenas democrática dos séculos V-IV as assistências que os podiam apreciar e recompensar melhor. 
Às suas conferências (epideixeis: "exibições”) assistia quem queria e podia lhes pagar, estendendo-se os preços, de uma ou um punhado de dracmas, a quantias consideráveis (como será o caso dos cursos de formação ministrados por Protágoras, frequentemente referidos por Platão nos diálogos (Protágoras 316c-319a; Mênon 91d-e; Teeteto 178e-179a)). Na falta de profissionais de advocacia, como "logógrafos" e praticantes da arte oratória, compunham discursos escritos que os clientes deveriam memorizar para os poderem recitar no tribunal. Alguns eram, como Górgias, mestres de Retórica, e deixaram-nos discursos paradigmáticos (além de fragmentos de discursos, como o Elogio de Helena e a Defesa de Palamedes: DK82B8, 9). Outros compuseram compêndios que expunham sistematicamente as regras da arte (technai: ver enumeração esboçada por Platão, no Fedro 266c-274b).

Independentemente das polêmicas a que deram origem, é inegável a sua importância para a História da Educação. Foram os primeiros a ser reconhecidos em vida como profissionais de ensino: homens "sabedores" (sophistai), mas não "sábios" (sophoi), representantes de um "saber" antiquíssimo, fixado na memória coletiva, como os "Sete Sábios" (Platão, Protágoras 343a-b; DK11A3). 
Também terão sido os primeiros a utilizar "livros" (textos redigidos em folhas de papiro para memorização e consulta dos seus discípulos) como instrumento pedagógico. Apesar de as divergências e polêmicas sobre a legitimidade da sua empresa didática estenderem-se por séculos (a partir do Fedro platônico, cuja posição sobre a Arte Retórica é ambivalente, ao contrário da demolidora crítica articulada no Górgias), o valor da sua contribuição para o desenvolvimento da filosofia não pode ser contestado. Atestam-no as denúncias críticas às utilizações a que se prestam as suas contribuições para o desenvolvimento das técnicas argumentativas sejam erísticas (para uso em disputas verbais), sejam retóricas (visando persuadir as audiências). Vemo-las expressas tanto nos diálogos que constituem a problemática em que assenta o programa da epistemologia platônica (Eutidemo, República, Crátilo, Teeteto, Sofista), como nos dois últimos tratados do Organon aristotélico (Tópicos e Refutações sofísticas).

Passamos agora à apresentação dos textos incluídos nesta coletânea. A seção poética que a inicia agrega três estudos. Seguindo a ordem pela qual são aqui apresentados, os dois primeiros são dedicados à abordagem da função educativa da 
poesia grega. O artigo de André Malta - "A sina de Odisseu e o que o Nome ensina" - trabalha com a etimologia fantasiosa do nome do herói que conhecemos como "Ulisses". Visa à finalidade de mostrar que a proximidade do nome "Odisseu" com o verbo odussomai ("irritar-se com", "irritar") faz dele um predestinado, anunciando e de algum modo explicando o seu fado como efeito da cólera vinda dos deuses.

Longe de constituir uma curiosidade, conjecturada para deleite de aficionados helenistas, a proposta ilustra a função educativa dos Poemas Homéricos, mostrando, no plano da linguagem, como os nomes (onomata), próprios ou comuns, são vistos como abreviaturas, construídas pela contração de expressões frásicas (rhêmata), a um tempo, designativas e descritivas (como Sócrates alega, no Crátilo platônico, 399b, com a concordância tácita da personagem que dá nome ao diálogo).

$\mathrm{O}$ artigo intitulado "Paideia na 'Lírica' Grega Arcaica: A Poesia Elegíaca e Mélica” - de autoria de Giuliana Ragusa e Rafael Brunhara - ilustra uma pletora de aspectos literários, culturais e sociais, associando o divertimento produzido pela performance à instrução e reflexão induzida nos participantes nos symposia ("banquetes"). Concentrado na análise dos exemplos fornecidos pela Elegia, de Teógnis, e pelo Partênio, de Álcman, insere nos 
ensinamentos declamados, cantados e representados a lição a incorporar pela assistência.

Ainda incluído neste grupo, o artigo "A Educação Trágica", assinado por JAA Torrano, apresenta os antecedentes da tragédia, as suas relações com o estado ateniense e sua importância no calendário das festas oficiais e na vida política da cidade. A estrutura e o conteúdo doutrinário do gênero são documentados pelas análises das Tragédias Os Persas e Agamêmnon, de Ésquilo, a partir das quais será examinado o modo trágico de propor reflexão, com vista à reatualização dos valores tradicionais. Na síntese com a qual termina o seu estudo, o A. reflete sobre o conteúdo e as finalidades da mensagem educativa dos Trágicos. Sem propor explicitamente comportamentos paradigmáticos, o tragediógrafo explora a representação de conflitos com vista a recontextualizar na Atenas do séc. V as ações dos heróis épicos.

Esse primeiro grupo de textos lança relances pontuais sobre a evolução do processo da educação grega. Vemo-lo passar, da lição colhida indiretamente pelo ouvinte da declamação do texto homérico, às performances pelas quais as assistências são levadas a participar ativamente na recontextualização da sua própria história, no tempo e espaço das cidades arcaica e clássica. É a partir desse momento que iremos ser confrontados com a eclosão da 
revolução crítica, registrada e simultaneamente produzida pela difusão do letramento.

Embora não tenham sobrevivido manuscritos anteriores ao séc. IV, a crer nos catálogos das obras dos pensadores gregos, elencados cerca de seiscentos anos mais tarde, por Diógenes Laércio, na sua obra Vidas e sentenças dos filósofos ilustres, só a partir do último quartel do séc. V se iniciará a composição e a difusão de textos filosóficos originais tanto de gênese oral, como escritural.

Talvez por ser paradigmático das dificuldades geradas nessa fase do letramento, na qual se torna impossível distinguir com nitidez a função desempenhada pela oralidade na composição de obras de gênese escritural, a História coloca Sócrates na charneira entre duas Grécias, a arcaica e a clássica. Certo é que nunca, antes ou depois, a uma personalidade a quem nenhum escrito pode ser atribuído, é referida tão extensa e diversificada produção de ideias, que até muito depois a literatura não cessará de ecoar.

Por isso é tão debatida a posição da figura de Sócrates no processo educativo grego, aqui abordado por Roberto Bolzani $\mathrm{F}^{\mathrm{o}}$, no estudo intitulado: "Educação socrática". O seu objetivo principal é apresentar e comentar as principais características da filosofia socrática, tal como os diálogos platônicos a elaboram, visando à 
compreensão do sentido em que essa filosofia constituirá uma forma de ensino e aprendizado.

Depois de uma abordagem biográfica do Mestre de Platão, agregando dados históricos relativos à Atenas dos meados do séc. V, o A. traça um esboço da chamada "Questão Socrática”. Entre as contrastantes imagens do pensador, colhidas em Aristófanes, Xenofonte e Platão, sem tomar partido sobre a sua historicidade, partindo da Apologia, elege o "Sócrates platônico" como a figura que "fornecerá elementos para pensar o tema da educação no pensamento socrático". Com o objetivo inicial de demarcar o filósofo de sofistas e de retóricos, com quem é por vezes confundido por concidadãos, por um lado denuncia a deficiência e a vanidade dos propósitos daqueles, por outro, ensaia a definição do projeto da filosofia, adotado por Platão.

Concentrado no problema do "saber socrático", o estudo passa então a clarificar a função purificadora da aporia, pela qual, refutando os seus interlocutores, o filósofo tenta estimular neles uma prática da "crítica", instigada pelo exercício da "autocrítica". Através da abordagem de alguns diálogos, considerados "socráticos", o A. desvela a estratégia "exemplar" mediante a qual, sem se comprometer com propósitos doutrinais, o filósofo consegue conferir ao seu ensino um alcance incontestavelmente formativo. A terminar, passando a referências a diálogos 
habitualmente atribuídos à "maturidade" de Platão, o A. encontra numa pontual análise do Mênon o exemplo de uma concretização do projeto da "maiêutica", tal como é descrito no Teeteto.

A exploração da proximidade entre os dois pensadores é frutuosa. No entanto, se aponta uma estrada real para o conhecimento da filosofia platônica, a concentração na figura de Sócrates contribui para o obscurecimento da contribuição dos sofistas para o projeto educativo grego. Para colmatar esta lacuna, o estudo de Gabrielle Cavalcanti, "A educação sofística”, dedica-se ao aprofundamento de um lugar-comum entre helenistas: o de que, durante o século $\mathrm{V}$, a educação propriamente dita desenvolveu-se em Atenas graças às práticas introduzidas pelo chamado "movimento sofístico".

Sendo os sofistas considerados os primeiros "docentes profissionais" que cobravam pelo seu ensino, a A. caracteriza a atividade a que se dedicam, chamando a atenção para o fato de tal caracterização não poder ser atestada pelos fragmentos que deles nos chegaram. Recorre então à análise do testemunho de Platão nos diálogos, sobretudo no Protágoras e no Górgias, para chegar à definição dos objetos, métodos e destinatários do ensino desses dois sofistas, em particular.

Tendo assinalado como objetivo principal do ensino sofístico a habilitação para falar em assembleias, enumera a seguir a 
diversidade de tópicos, de currículos e de metodologias, coberta pelos mais renomados praticantes da arte, não deixando de mencionar a novidade do instrumental pedagógico e didático a que recorriam. Concentra-se depois na análise dos documentos que nos permitem ter uma ideia das práticas de ensino levadas a cabo por figuras como Górgias, Protágoras, Pródico, Hípias e Antifonte, além de outros, considerados menores.

Nesse domínio, dedica ainda atenção a dois escritos anônimos - os Discursos Duplos e o Anônimo de Jâmblico -, fechando a sua contribuição com a exposição de três tópicos candentes que os percorrem: o envolvimento dos sofistas com o ensino da "virtude" (arete), a controvérsia entre a lei (nomos) e a "natureza" (physis), na política e na moral, convergindo no debate acerca de possibilidade de a virtude ser ensinada.

O artigo de Carolina Araújo - "A função educativa da ginástica na República de Platão" - denuncia e chama a atenção para a habitual subvalorização do papel da ginástica no projeto da cidade platônica. $\mathrm{O}$ estudo mostra que a introdução da ginástica no projeto educativo do Mestre da Academia não deve se limitar a constituir a mera continuidade com a educação tradicional (como pode sugerir uma leitura apressada do passo da República 376e). Defende a A. haver na proposta educativa de Platão dois conceitos de ginástica, cada um dos quais se associa à prática de uma virtude 
específica: a temperança e a coragem. Respeitando a distribuição das virtudes pelas três classes da polis, enquanto a primeira se destina a todos os cidadãos e é uma autoeducação relativa ao cuidado do corpo, dependendo da educação pela poesia, a outra é uma prática funcionalmente especializada dos guardiões. Consiste em treinamento atlético, visando ao fortalecimento da parte impetuosa da alma e da cidade e à preparação para o regime de resistência demandado aos guardiões enquanto exercem seu cargo.

É no Livro VIII da Política - que chegou até nós incompleto - que Aristóteles se confronta com a educação. Depois de esboçar um currículo básico no qual inclui quatro disciplinas - gramática, ginástica, música e, para alguns, desenho -, segue o seu Mestre Platão, ao distinguir a ginástica que serve a arte militar (privilegiada em Esparta) daquela que visa ao cuidado do corpo, insistindo em que nunca poderá prejudicar o desenvolvimento do espírito. Quanto à Música, defende que deve educar pelo ritmo e pela melodia, por estes serem considerados imitações da natureza. Praticando os diversos modos musicais, a disciplina cultivará aqueles que proporcionam "o prazer elevado", respeitando o ócio, porém, evitando os perigos resultantes do afrouxamento da finalidade instrutiva.

Todo este programa é determinado pela consideração das finalidades a visar com o processo do ensino e aprendizagem, 
inquirindo se deve se educar para a utilidade ou para a virtude. $\mathrm{Na}$ sua resposta, o filósofo atende a ambas as finalidades mostrando que, se há que respeitar a utilidade, pois convém ao homem livre, haverá, porém, que ter sempre o cuidado de preservar a virtude.

Um eco desta contraposição é analisado pelo estudo de Lucas Angioni - "O ser humano cultivado (pepaideumenos) em Aristóteles" -, concentrado na equação do tipo de conhecimento próprio do homem cultivado com o daquele que "tem conhecimento científico do assunto" (no sentido de ser capaz de conhecer a sua causa). Todo o argumento, elaborado a partir da confrontação de diversos textos de Aristóteles, atinge, em comparação com o tratamento da educação pela parte de Platão, um patamar crítico muito mais elevado. Longe de se concentrar na análise da educação como projeto político, partindo implicitamente da sua própria concepção de conhecimento, o Estagirita medita sobre a necessidade de ver respeitados dois tipos de formação: de um lado, a daquele a quem ele chama "filósofo"; do outro, a daquele a quem, só a partir da contemporaneidade, se começará a chamar "cientista".

Nesta breve introdução, foi nosso objetivo conferir unidade ao conjunto de estudos aqui reunidos. Tentamos apontar o papel desempenhado por Homero e pela tradição literária que parte da 
composição por escrito dos Poemas para fixar a identidade cultural dos Gregos na língua comum a todos.

Aprofundando esta linha interpretativa, referimos depois a função do gradual processo de letramento da cultura no projeto educativo grego. Começando pela criação de escolas que visavam à aquisição pelos jovens das competências básicas - ler, escrever e contar -, a educação grega vai se acomodando à participação dos primeiros profissionais do ensino - os sofistas - no esboço de uma educação superior, politicamente inserida.

Numa linha paralela a esta, em diálogo, muitas vezes polêmico com ela, a tradição, que Platão e Aristóteles ideologicamente caracterizam como "filosófica", isola o ideal do conhecimento, chegando a separar a pesquisa do processo do ensino/aprendizagem, cuja finalidade é agilizar a inserção social das classes não aristocráticas, recém-chegadas ao poder.

\section{Referência}

PLATÃO. Protágoras - Górgias - Fedão. 2.ed. revisada. Trad. Carlos Alberto Nunes. Belém: EDUFPA, 2002. 